\title{
Ímyndarpættir sem spávísar um traust í bankageiranum
}

\author{
Pórhallur Guðlaugsson og Friðrik Larsen ${ }^{1}$
}

\begin{abstract}
Ágrip
Í pessari grein er leitast við að svara eftirfarandi rannsóknarspurningum: Hvaða imyndarpættir spá fyrir um traust til íslenskra banka og hvaða imyndarpættir hafa mest vægi pegar spáð er fyrir um traust til íslenskra banka? Niðurstöður rannsóknarinnar eru að stærstum hluta byggðar á tveimur könnunum frá 2013 og 2014 en einnig nokkrum sambærilegum könnunum sem gerðar hafa verið á bankakerfinu, bæði fyrir og eftir bankahrunið 2008. Niðurstöður rannsóknarinnar leiða í ljós fjóra pætti sem skýra rúm $68 \%$ af breytileikanum í trausti. Pessir pættir eru: samfélagsleg ábyrgð, að leggja góðum málum lið, spilling og persónuleg pjónusta. Af pessum fjórum páttum er samfélagsleg ábyrgð mikilvægastur.
\end{abstract}

\begin{abstract}
This paper deals with the following two research questions: Which image attributes predict the image of trust? and Which attributes are most important in predicting the level of trust? The research findings are based on a series of image surveys of the banking sector conducted before and after the Icelandic banking crisis. The results show that four dimensions explain $68 \%$ of the variability in trust. Those dimensions are social responsibility, supporting good causes, corruption and personal service. Out of these social responsibility is the most important item.
\end{abstract}

JEL flokkun: K2, L4

Efnisorð: Ímynd, imyndarmælingar, viðskiptabankar, traust.

\section{Inngangur}

Í byrjun 21. aldarinnar óx íslenska bankakerfið hratt og varð að tífaldri landsframleiðslu í lok ársins 2007 (Ríkisendurskoðun, 2009). Haustið 2008 varð mikil breyting á íslenska bankakerfinu í framhaldi af bankahruninu. Á aðeins fáum dögum höfðu prír stærstu bankarnir, Íslandsbanki/Glitnir, Arion banki/Kaupping og Landsbankinn allir orðið gjaldprota, en saman höfðu peir að geyma mesta sparnað og lánveitingar landsmanna og voru ábyrgir fyrir um 85\% af heildareignum í bankakerfinu (Ríkisendurskoðun, 2009). Næstu ár á eftir urðu einnig stærstu sparisjóðirnir gjaldprota. Afleiðingarnar hafa verið

\footnotetext{
${ }^{1}$ Dr. Pórhallur Guðlaugsson er dósent í viðskiptafræði við Viðskiptafræðideild Háskóla Íslands. Dr. Friðrik Larsen er lektor í viðskiptafræði við Viðskiptafræðideild Háskóla Íslands. Höfundar pakka tveimur ónafngreindum ritrýnum og ritstjóra fyrir gagnlegar ábendingar.
} 
alvarlegar fyrir íslenska efnahagskerfið og einnig hefur ímynd bankanna skaðast. Spilling tengist nú fremur ímynd peirra og að sama skapi hefur verulega dregið úr trausti. Fyrir bankahrunið var pessi geiri með sterka tengingu við jákvæða ímyndarpætti, hjá bönkunum var eftirsótt að vinna og peir nutu jafnvel aðdáunar. Í pessari grein er áhersla lögð á að skoða ímyndarpáttinn traust og hvaða aðrir ímyndarpættir geta skýrt breytileikann í trausti. Eftirfarandi rannsóknarspurningum er svarað:

1. Hvaða ímyndarpættir spá fyrir um traust til íslenskra banka?

2. Hvaða ímyndarpættir hafa mest vægi pegar spáð er fyrir um traust til íslenskra banka?

Traust er mikilvægur páttur í öllum viðskiptum og skiptir miklu máli fyrir nútímafyrirtæki. Á pað bæði við um fyrirtækja- og neytendamarkað, hjá stofnunum, í rafrænum viðskiptum og hjá skipulagsheildum sem ekki hafa hagnað sem meginmarkmið (non profit markets). Ekki er hægt að skilgreina traust á einfaldan máta en líta má á traust sem ímyndarpátt eða ímyndarvídd. Par af leiðandi er mikilvægt að hafa haldgóðan skilning á peim páttum sem notaðir eru til að skýra breytileika í trausti.

Helstu niðurstöður pessarar rannsóknar eru byggðar á tveimur samskonar könnunum sem gerðar voru í febrúar 2013 (n=565) og febrúar 2014 (n=423). Enginn tölfræðilegur munur var á milli pessara tveggja rannsókna hvað afstöðu til ímyndarpátta varðar og pví voru pær sameinaðar í einn gagnagrunn með samtals 987 svörum. Eftir hreinsun gagnasafnsins stóðu eftir 881 svar. Til að sýna próun í mati á ímyndarpáttunum trausti annars vegar og spillingu hins vegar er stuðst við gögn frá árunum 2006-2012 en könnunin hefur verið framkvæmd árlega með sama hætti. Pessari grein er skipt upp í fjóra kafla. Í fyrsta kaflanum er greint frá fræðilegu yfirliti og fjallar annar kafli um aðferðafræði rannsóknarinnar. Greint verður frá niðurstöðum rannsóknar í priðja kafla og í fjórða kafla er umræða um niðurstöður og frekari rannsóknir á efninu.

\section{Fræðilegt yfirlit}

Töluvert hefur verið fjallað um áhrif bankahrunsins árið 2008 á íslensku bankanna og hefur verið sýnt fram á að traust til peirra hefur minnkað umtalsvert (De Bondt, 2010; Rambocas og Kirpalani, 2014; Pórhallur Guðlaugsson og Friðrik Eysteinsson, 2010). Ímynd bankanna er mótuð af bæði hagnýtum og tilfinningalegum viðhorfum til peirrar pjónustu sem í boði er (Chen, Chang og Chang, 2005; O’Loughlin og Szmigin, 2005), svo sem frammistöðu starfsfólks, staðsetningar, aðgengis, alpjóðlegra áhrifa og samfélagslegrar ábyrgðar (Bravo, Montaner og Pina, 2009). Sýnt hefur verið fram á að pað síðastnefnda, samfélagsleg ábyrgð, er að verða sífellt mikilvægari fyrir banka (Branco og Rodrigues, 2006; Souiden, Kassim og Hong, 2006). Ímynd er byggð á mismunandi breytum sem ganga út á að skýra neytendahegðun (Hsieh, Pan og Setiono, 2004). Petta eru óefnislegir pættir sem tengjast vöru eða pjónustu og hafa áhrif á mat neytandans á vörumerkinu og pví forskoti sem peir telja pað hafa (Yoo, Donthu og Lee, 2000). Í gegnum ímynd vörumerkis geta neytendur gert greinarmun á mismunandi vörum, metið gæði, lágmarkað kaupáhættu og viðhaldið ánægjustigi (Lin og Lin, 2007). Pví hefur áhugi á að rannsaka ímynd aukist síðustu ár (sjá t.d. Ballantyne og Aitken, 2007; Merz, He og Vargo, 2009).

Í eldri rannsóknum er hægt að sjá hvernig tímapætti er bætt við skilgreiningu ímyndar. Pannig skilgreinir Howcroft (1991) ímynd fyrirtækja sem samansafn af áhrifum og 
væntingum sem próast yfir tíma og Keller (1993) sem skynjanir og tengsl í huga einstaklinga. Loks skilgreinir Fombrun (1996) ímynd sem huglæga lýsingu sem neytandinn mótar í gegnum samansafn af margskonar skilaboðum sem fengin hafa verið í gegnum tíðina. Með pessu viðhorfi er hægt að líta á ímynd sem síbreytilegt og gagnvirkt hugtak sem tekur bæði tillit til fortíðar og nútíðar eftir pví hvernig hver og einn einstaklingur skilgreinir pað (Keller, 2008; Rindell, 2013; Solms og Turnbull, 2002). Samkvæmt framangreindu hafa fyrri gjörðir fyrirtækja umtalsverð áhrif á hvernig neytandinn skynjar ímynd peirra. Pannig má ganga út frá pví að ímynd sé ekki sérstætt og einangrað hugtak heldur flókið og margpætt sem á upptök sín í pví liðna sem hefur pannig áhrif á núverandi framsetningu og pað hvernig hver einstaklingur bregst við aðgerðum fyrirtækisins (Braun-LaTour, LaTour og Zinkhan, 2007; Brown, Dacin, Pratt og Whetten, 2006; Dutton og Dukerich, 1991, 2004; Rindell, 2007). Pá hefur Rindell (2013) vakið athygli á pví að tímapáttur í uppbyggingu ímyndar hefur lítið verið rannsakaður, pó svo að eldri rannsóknir sýni að vöruímynd sé breytileg og próist yfir langan tíma (Gardner og Levy, 1955). Рað er pví áhugavert að sjá hvaða áhrif atburður eins og bankahrun hefur á ímynd bankanna, ímynd sem hefur verið í stöðugri mótun í áratugi.

Viðskiptavinatryggð er djúpstæð skuldbinding neytenda til pess að halda sífellt áfram að kaupa ákveðið vörumerki, vöru eða pjónustu, eða velja að eiga viðskipti við ákveðið fyrirtæki til lengri tíma. Рað á við prátt fyrir að ný skilyrði skapist eða að samkeppnisaðili hvetji pá til að færa viðskipti til peirra (Davis-Sramek, Droge, Mentzer og Myers, 2009; Flint, Blocker og Boutin Jr., 2011; Lov og Wirtz, 2011; Oliver, 1997). Tryggir viðskiptavinir eru mikilvægir (Tsai, 2011) par sem pað er ódýrara að pjónusta pá (Shugan, 2005), peir eru tilbúnari til að kaupa stærri einingar, borga meira og eru jákvæðir í umtali (Reichheld og Sasser Jr., 1990). Að hafa trygga viðskiptavini hefur fleiri jákvæða kosti í för með sér, s.s. að minna fjármagni er varið í markaðsaðgerðir sem eiga að laða að nýja viðskiptavini og betur er haldið í núverandi viðskiptavini sem leiðir til hærri vörumerkjavitundar og hagnaðar (Smit, Bronner og Tolboom, 2007).

Rannsóknir sem gerðar hafa verið á tryggð í bankageiranum gefa til kynna að tryggð sé fremur afleiðing af vitsmunalegu ferli en tilfinningalegu. Til pess að eignast trygga viðskiptavini eru mikilvægustu pættirnir ímynd, traust, ánægja, skynjað virði og pjónustugæði. Pessi hugtök eru að stórum hluta tengd innbyrðis og mynda ákveðið net af tryggðaratvikum (Lewis og Soureli, 2006). Nýrri rannsóknir hafa staðfest mikilvægi nefndra pátta en að auki bætt við mikilvægi samfélagslegrar ábyrgðar fyrirtækja (Zahir, 2014).

Traust tekur til einstaklinga, fyrirtækja eða stofnana (Jones, Wilkens, Morris og Masera, 2000) og skortur á trausti getur leitt til óhagræðis í samkeppnislegu tilliti (Barney og Hansen, 1994). Rannsóknir benda til að traust sé ráðandi páttur pegar kemur að áætlunum um endurkaup (Doney og Cannon, 1997). Traust er vilji til að reiða sig á annan aðila sem pykir traustsins verður (Moorman, Zaltman og Deshpande, 1992), trú á að loforð aðilans séu áreiðanleg og að hann muni uppfylla sínar skyldur í sambandinu. Traust er mikilvægur páttur í öllum tegundum viðskipa hvort sem átt er við fyrirtæki á neytendamarkaði (Chatura og Prabhu, 2003; Pennington, Wilcox og Grover, 2004), á fyrirtækjamarkaði (Blois, 1999), meðal stofnana (Holland, 1998), í rafrænum viðskiptum (Gefen, 2000; Ratnasingham, 1998) og á mörkuðum sem ekki eru reknir í hagnaðarskyni (Bunger, 2013; Gilbert og Behnam, 2013). Pó hafa rannsóknir ekki endanlega sýnt fram á hvort traust sem hugtak sé ein vídd eða samsetning margra vídda, enda er traust flókið og fjölpætt hugtak (Xie og Peng, 2009). Kantsperger og Kunz (2010) taka fram að traust hafi tvær víddir, trúverðugleika og velgjörð. Sirdeshmukh, Singh og Sabol (2002, bls. 17) skilgreina traust sem „væntingar viðskiptavina 
um að pjónustuaðili sé áreiðanlegur og hægt sé að treysta á að hann muni uppfylla loforð sín“.

Bæði traust og ánægja hafa sterk jákvæð áhrif á hversu líklegir viðskiptavinir eru til að halda áfram í viðskiptum (Chatura og Prabhu, 2003; Schurr og Ozanne, 1985). Sýnt hefur verið fram á að traust og ánægja viðskiptavina eykur tryggð, endurkaup, hagnað til lengri tíma og jákvætt umtal (Wirtz, 2003). Traust og ánægja eru mjög tengd hugtök og sumar skilgreiningar á trausti innihalda jafnframt ánægju sem einn af uppistöðupáttum trausts (Sirdeshmukh o.fl., 2002). Saman veita traust og ánægja nauðsynleg skilyrði fyrir viðvarandi tengsl á milli viðskiptavinar og vörumerkis er einkennist af trúfestu eða tryggð (Hess og Story, 2005). Einnig hefur verið lögð áhersla á að sýna fram á mikilvægi ánægju viðskiptavina í bankageiranum og ómissandi hlutverk hennar pegar kemur að pví að viðhalda viðskiptum (Farquhar og Panther, 2008). Jafnframt hefur verið sýnt fram á að ánægja er lykilbreyta í áformum viðskiptavina um að nota áfram pjónustu bankanna (Bravo et al., 2009) en eins og kemur fram framar eru sterk tengsl á milli ánægju annars vegar og trausts hins vegar.

\section{3 Аðferð}

Söfnun gagna fór fram í febrúar 2013 (n=564) og febrúar 2014 (n=423). Enginn tölfræðilegur munur var á milli pessara tveggja rannsókna hvað afstöðu til ímyndarpátta varðaði og voru pær pví settar saman í einn gagnagrunn.

\subsection{Dýdi og úrtak}

Pýði rannsóknarinnar samanstóð af viðskiptavinum banka og sparisjóða en í rannsókninni var notað hentugleikaúrtak með heildarfjölda svara 987. Pegar tekið hafði verið tillit til hálfkláraðra svara og frávillinga voru gild svör 881. Bæði árin voru framkvæmdar tvær samskonar kannanir á sama tíma. Önnur fór fram meðal nemenda við Háskóla Íslands en hin meðal almennings. Kannað var hvort munur væri á milli peirra hvað afstöðu til ímyndarpátta varðaði og kom í ljós að svo var ekki. Pá var, eins og áđur segir, kannað hvort munur væri á milli ára og kom í ljós að ekki kom fram munur hvað afstöðu til ímyndarpátta varðaði. Í töflu 1 má sjá samsetningu úrtaksins m.t.t. kyns og aldurs.

Tafla 1: Samsetning úrtaksins m.t.t. kyns og aldurs

\begin{tabular}{|r|c|c|cc|c|}
\hline & \multicolumn{2}{|c|}{2013} & \multicolumn{2}{c|}{$\mathbf{2 0 1 4}$} & \\
\hline & Hí hluti & A hluti & HÍ hluti & A hluti & Sam/með \\
\hline Gild svör: & 276 & 228 & 249 & 128 & 881 \\
\hline Karlar: & $31,4 \%$ & $40,1 \%$ & $27,9 \%$ & $54,2 \%$ & $38,4 \%$ \\
Konur: & $68,6 \%$ & $59,9 \%$ & $72,1 \%$ & $45,8 \%$ & $61,6 \%$ \\
\hline Yngri en 20 ára: & $0,4 \%$ & $12,3 \%$ & $0,4 \%$ & $0,8 \%$ & $3,5 \%$ \\
\hline $\mathbf{2 0 - 2 4}$ ára: & $25,0 \%$ & $10,1 \%$ & $25,7 \%$ & $9,2 \%$ & $17,5 \%$ \\
$\mathbf{2 5 - 2 9}$ ára: & $19,9 \%$ & $4,8 \%$ & $15,5 \%$ & $23,5 \%$ & $15,9 \%$ \\
\hline $\mathbf{3 0 - 3 9}$ ára: & $22,8 \%$ & $34,8 \%$ & $23,0 \%$ & $36,9 \%$ & $29,4 \%$ \\
40 ára eða eldri: & $31,9 \%$ & $37,9 \%$ & $35,4 \%$ & $29,4 \%$ & $33,7 \%$ \\
\hline
\end{tabular}


Svör pátttakenda endurspegluðu vel markaðshlutdeild priggja stærstu bankanna, par sem hver banki er með um 30\% hlutdeild (Samkeppniseftirlitið, 2011)2. Einnig er viðhorf pátttakenda sambærilegt mörgum öðrum rannsóknum um viðhorf til bankanna ${ }^{3}$. Par af leiðandi er hægt að meta pað sem svo að niðurstöðurnar séu góð vísbending um viðhorf til bankanna, miðað við pá ímyndarpætti sem notaðir voru.

\subsection{Mrlitæki}

Peir ímyndarpættir sem notaðir voru í pessari rannsókn voru skilgreindir í viðamikilli rannsókn, sem fólst í viðtölum við viðskiptavini bankanna, stjórn peirra og starfsfólk, ítarlegri skoðun á vefsíðum og greiningu á almennri fjölmiðlaumfjöllun um banka og sparisjóði. Rannsóknin hefur verið framkvæmd árlega í febrúar/mars með svipuðu sniði síðan 2004 (sjá t.d. Pórhallur Guðlaugsson, 2008; Pórhallur Guðlaugsson og Friðrik Eysteinsson, 2010).

Í fyrsta hluta rannsóknarinnar voru pátttakendur beðnir um að meta bankana miðað við ákveðna pætti, sem eru: leggur góðum málum lið, framsækni, nútímalegur, spilling, gamaldags, persónuleg pjónusta, samfélagsleg ábyrgð og traust. Í pessari rannsókn er traust notað sem háð breyta á meðan aðrar eru óháðar og notaðar til að skýra breytileikann í trausti.

Pátttakendurnir lögðu mat á hvern banka fyrir sig út frá hverjum eiginleika með pví að nota níu stiga kvarða par sem 1 stóð fyrir á mjög illa við pennan banka/sparisjóð og 9 stóð fyrir á mjög vel við pennan banka/sparisjóð. Í rannsókninni voru pátttakendurnir einnig spurðir um almennt viðhorf til bankanna, tryggð peirra og hvort peir hefðu skipt um banka eða sparisjóð á undanförnum sex mánuðum. Í pessari grein eru aðeins notaðar niðurstöður ímyndarpáttanna.

\subsection{Framkvæmd}

Spurningalistinn var rafrænn og var lagður fyrir almenning og nemendur í Háskóla Íslands í febrúar 2013 og endurtekinn með sama hætti á sama tíma árið 2014. Par sem enginn tölfræðilegur munur var á milli pessara tveggja rannsókna voru pær sameinaðar og var pá heildarfjöldi svara 987. Til að byrja með var meðalgildi ímyndarpáttanna reiknað til að kanna hvort bankarnir höfðu náð að viðhalda fyrri ímynd. Hefðbundin margvíð aðhvarfsgreining (multiple regression analysis) var notuð til að spá fyrir um traust (enter method).

Í aðhvarfsjöfnunni (bivariate regression equation) er traust háða breytan en aðrir ímyndarpættir óháðir og notaðir til að skýra breytileikann í trausti. Margvíð aðhvarfsgreining er viðeigandi par sem hún skilgreinir hvaða pættir eru tengdir við háðu breytuna og hvernig hver páttur hefur áhrif á háðu breytuna sem og innbyrðis vægi peirra. Pó að allar óháðu breyturnar séu á sama kvarða (kvarði 1-9) er staðlaður beta stuðull notaður til að ákvarða hlutfallslegt vægi peirra (Burns og Bush, 2006) að pví gefnu að öðrum sé haldið föstum. Frávillingum (outliers) var eytt úr gagnasafninu til að auka gæði aðhvarfsgreiningarinnar. Рað sem einkenndi pá frávillinga sem eytt var út úr gagnasafninu var að svarið endurspeglaði ýmist eða bæði öfgafulla svörun eða afstöðulausa svörun. Dæmi um pað var pegar svarandi gaf öllum bönkum 1 eða 9 fyrir ímyndarpátt og svarandi kom fram sem frávillingur samkvæmt greiningu (Boxplot). Pá kom í ljós að gögnin uppfylltu viðmið normaldreifingar (Normal P-P plot og Scatterplot) sem og um marglínuleika (VIF < 5 og

\footnotetext{
2 Einnig byggt á munnlegri heimild stjórnenda priggja stærstu bankanna.

${ }^{3}$ Munnleg heimild stjórnenda priggja stærstu bankanna.
} 
Tolerance > 0,2). Hæsta gildið fyrir VIF var 2,2 og lægsta gildið fyrir Tolerance 0,457 pegar horft er til peirra ímyndarpátta sem höfðu marktæka stuðla í líkaninu.

\subsection{Takmarkanir}

Ein takmörkun rannsóknarinnar er sú að notað var hentugleikaúrtak og meirihluti pátttakenda var kvenkyns. Önnur takmörkun var sú að rannsóknin var einungis gerð í einu landi, í framhaldi af ákveðnu bankahruni. Takmarkar petta pví möguleikann á að geta alhæft um niðurstöðurnar. Par sem um pægindaúrtak er að ræða lýsir niðurstaðan aðeins afstöðu úrtaksins. Við frekari rannsóknir væri möguleiki að nota handahófs úrtak og leggja fyrir viðskiptavini í fleiri löndum.

\section{Niðurstöður}

Niðurstöðukafla er skipt upp í fjóra hluta. Í fyrsta hluta er pátttakendum lýst og í öðrum hluta er meðaltal ímyndarpátta áranna 2006 til 2014 reiknað og sett fram. Priðji hluti skilgreinir pá pætti sem spá fyrir um traust (1. rannsóknarspurning) og fjórði hlutinn segir til um hlutfallslegt mikilvægi peirra (2. rannsóknarspurning) byggt á Beta stuðlum sem segir til um framlag hverrar breytu fyrir sig pegar öðrum er haldið föstum.

\subsection{Dátttakendur}

Pátttakendur í rannsókninni voru 881 (gild svör) og par af voru tæp 62\% konur. 66,3\% voru yngri en 40 ára og 33,7\% voru 40 ára eða eldri. Samkvæmt Hagstofunni (sjá hagstofa.is) voru konur tæp 50\% pjóðarinnar árið 2013 en 35,9\% voru 40-70 ára. Úrtakið endurspeglar pví ágætlega pýðið hvað aldur varðar á meðan hlutfall kvenna er heldur hærra í úrtakinu.

Markaðshlutdeild bankanna milli peirra sem svöruðu rannsókninni er sambærileg peirri markaðshlutdeild sem á við pýðið í heild, eins og fram hefur komið. Pessir prír stærstu bankar (Landsbankinn, Arion banki og Íslandsbanki) hafa samanlagt um 95\% markaðshlutdeild hjá úrtakinu. Раð er pví mat höfunda að pátttakendur endurspegli ágætlega pann hóp sem er virkur í bankaviðskiptum.

\subsection{Meðaltal imyndarpátta}

Í töflu 2 má sjá meðalgildi ímyndarpátta frá árinu 2006 til ársins 2014. Eins og sjá má lækkuðu pau gildi sem snúa að jákvæðum ímyndarpáttum eftir hrunið (vor 2009) en hækkuðu jafnframt pegar kemur að neikvæða ímyndarpættinum spilling.

Tafla 2: Meðaltal ímyndarpátta 2006-2014

\begin{tabular}{|r|c|c|c|c|c|c|c|c|c|}
\hline & $\mathbf{2 0 0 6}$ & $\mathbf{2 0 0 7}$ & $\mathbf{2 0 0 8}$ & $\mathbf{2 0 0 9}$ & $\mathbf{2 0 1 0}$ & $\mathbf{2 0 1 1}$ & $\mathbf{2 0 1 2}$ & $\mathbf{2 0 1 3}$ & $\mathbf{2 0 1 4}$ \\
\hline Leggur góðum málum lið & 5,7 & 5,7 & 5,9 & 4,6 & 3,9 & 3,9 & 4,1 & 4,7 & 4,8 \\
Traust & 6,3 & 6,2 & 6,0 & 3,6 & 3,1 & 2,8 & 3,6 & 4,2 & 4,4 \\
Persónuleg pjónusta & 5,7 & 5,6 & 6,0 & 4,5 & 4,2 & 4,3 & 4,6 & 5,0 & 5,1 \\
Samfélagsleg ábyrgð & 5,2 & 5,1 & 5,4 & 3,0 & 2,7 & 2,4 & 3,2 & 3,8 & 3,9 \\
Framsækni & 5,3 & 5,2 & 6,3 & 4,6 & 4,2 & 4,0 & 4,4 & 4,8 & 5,1 \\
Nútímalegur & 6,4 & 6,2 & 6,5 & 5,3 & 5,0 & 4,8 & 5,2 & 5,5 & 5,6 \\
Gamaldags & 4,0 & 4,1 & 4,4 & 4,4 & 4,4 & 4,8 & 4,6 & 4,7 & 4,8 \\
Spilling & 4,1 & 4,2 & 5,0 & 6,6 & 7,0 & 7,4 & 6,9 & 6,7 & 6,3 \\
\hline
\end{tabular}

Ímyndarpátturinn traust lækkaði frá pví að vera 6,3 árið 2006 í 2,8 árið 2011. Eftir pað hækkaði hann örlítið og var gildi hans 4,4 árið 2014. Á sama tíma hafði gildið fyrir 
ímyndarpáttinn spillingu hækkað úr pví að vera 4,1 árið 2006 i 7,4 árið 2011. Eftir pað lækkaði hann örlítið og var 6,3 árið 2014. Pegar kemur að samfélagslegri ábyrgð er útkoman svipuð par sem gildi pess lækkaði úr 5,2 frá árinu 2006 í 2,4 árið 2011, sem er jafnframt lægsta gildið í töflunni.

Eins og fram hefur komið, er traust mikilvægur ímyndarpáttur pegar kemur að bankageiranum og er par af leiðandi áhugavert að skoða nánar hvernig próunin hefur verið. Einnig er áhugavert að kanna hvernig ímyndarpátturinn spilling hefur próast. Á mynd 1 má sjá meðalgildi fyrir traust og spillingu frá árinu 2006 fram til ársins 2014, en áhugavert er að sjá hvernig línurnar endurspegla nánast hvor aðra.

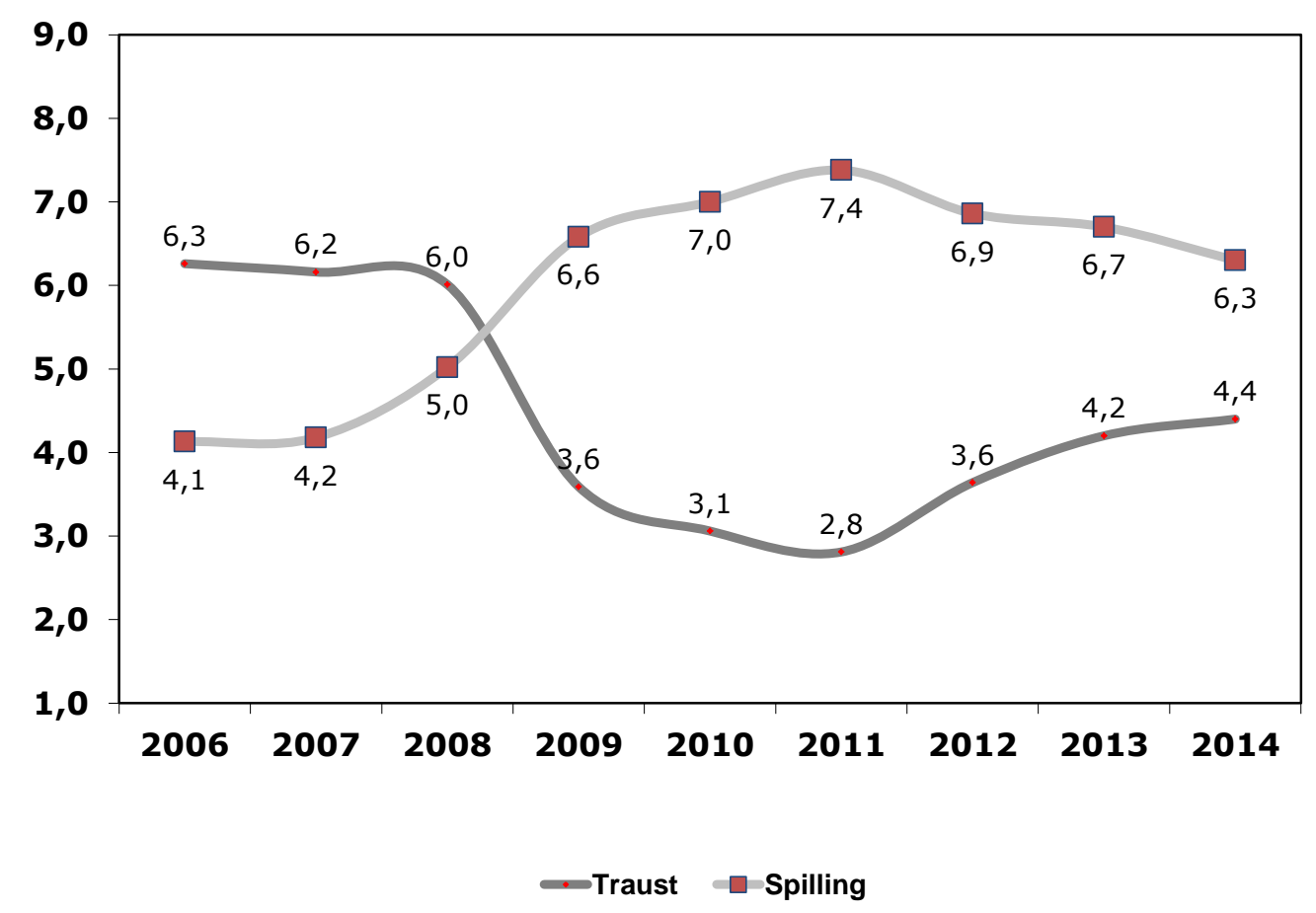

Mynd 1: Próun á ímyndarpáttunum traust og spillingu 2006-2014

Eins og sjá má á mynd 1 lækkaði meðalgildi fyrir traust mikið í framhaldi af hruninu og hélt áfram að lækka næstu tvö árin (2010 og 2011). Í rannsókninni sem gerð var árið 2012 hafði meðalgildi trausts pó hækkað og hélt áfram að hækka eftir pað og er meðalgildið árið 2014 раð hæsta $(4,4)$ síðan bankahrunið varð haustið 2008. Prátt fyrir pað lítur út fyrir að enn sé langt í land í meðalgildi áranna fyrir bankahrun.

Eins og áður var nefnt er áhugavert að sjá að meðalgildi spillingar speglar nánast meðalgildi trausts par sem pað hækkaði pegar meðalgildi trausts lækkaði. Niðurstöður gefa pó til kynna að ímynd bankanna sé á réttri leið, pó svo að enn sé langt í land eins og áður segir.

\subsection{Dættir sem spá fyrir um traust}

Í pessum hluta er áherslan lögð á að svara 1. Rannsóknarspurningu: Hvaða ímyndarpættir spá fyrir um traust til íslenskra banka? Fjórir af átta ímyndarpáttum voru tölfræðilega marktækir og útskýra peir $68,2 \%$ af breytileikanum í trausti $\left(R^{2}=0,682\right)$. Niðurstöðurnar má sjá í töflu 3. 
Tafla 3: Spálíkan fyrir traust

\begin{tabular}{|c|c|c|c|c|}
\hline \multicolumn{5}{|c|}{ Samantekið } \\
\hline Líkan & $\mathbf{R}$ & $\mathbf{R}^{2}$ & Aðlagað $\mathbf{R}^{2}$ & Staðalvilla \\
\hline 1 & 0,83 & 0,68 & 0,68 & 1,04 \\
\hline
\end{tabular}

Spávísar: (fasti), leggur góðum málum lið, persónuleg pjónusta, samfélagsleg ábyrgð, spilling

Peir fjórir ímyndarpættir sem voru tölfræðilega marktækir voru: Leggur góðum málum lið, persónuleg pjónusta, samfélagsleg ábyrgð og spilling. Allir höfðu jákvæða stuðla nema spilling, sem gefur til kynna að hærra mat á spillingu leiði til lægra mats á trausti. Petta er rökrétt par sem traust og spilling eru andstæðir ímyndarpættir eins og sjá má á mynd 1.

\subsection{Mikilvægustu imyndarpættirnir}

Í pessum hluta er áhersla lögð á að svara 2. rannsóknarspurningunni: Hvaða ímyndarpættir hafa mest vægi pegar spáð er fyrir um traust til íslenskra banka? Mikilvægt er að hafa í huga að ekki hafa allir ímyndarpættirnir sama hlutfallslega vægi pegar spá á fyrir um traust. Í töflu 4 má sjá niðurstöðurnar úr aðhvarfsgreiningunni og pá fjóra ímyndarpætti sem höfðu tölfræðilega marktæka stuðla.

Tafla 4: Ímyndarpættir úr aðhvarfsgreiningarlíkaninu

\begin{tabular}{|r|cc|c|c|c|c|c|}
\hline & B & Staðalvilla & $\begin{array}{c}\text { Stöðluð } \\
\text { Beta }\end{array}$ & $\mathbf{t}$ & p-gildi & Tol & VIF \\
\hline (Fasti) & 1,38 & 0,24 & & 5,71 & 0,000 & & \\
Leggur góðum málum lið & 0,26 & 0,03 & 0,22 & 7,59 & 0,000 & 0,48 & 2,07 \\
Persónuleg pjónusta & 0,31 & 0,03 & 0,29 & 10,18 & 0,000 & 0,52 & 1,94 \\
Samfélagsleg ábyrgð & 0,32 & 0,03 & 0,35 & 11,90 & 0,000 & 0,46 & 2,19 \\
Spilling & $-0,17$ & 0,03 & $-0,15$ & $-6,64$ & 0,000 & 0,77 & 1,30 \\
\hline
\end{tabular}

Háða breytan: Traust

Par sem jafna aðhvarfsgreiningar er $\mathrm{Y}=\alpha+\beta_{1}{ }^{*} \mathrm{x}_{1}+\beta_{2}{ }^{*} \mathrm{x}_{2} \ldots \beta_{\mathrm{n}}{ }^{*} \mathrm{X}_{\mathrm{n}}$ má segja að spálíkan fyrir breytileikann í trausti sé:

$$
\mathrm{Y}=1,38+0,26^{*} \text { leggur góðum málum lið+0,31* persónuleg pjónusta }+0,32 * \text { samfélagsleg ábyrgð- } 0,17^{*} \text { spilling }
$$

Par sem Y stendur fyrir traust sem er pað gildi sem er verið að spá fyrir um. Stuðlar (B) aðhvarfsjöfnunnar mæla hversu mikil áhrif hver ímyndarpáttur hefur á spágildið (predictive) á meðan að stöðluð beta segir til um framlag breytunnar við að spá fyrir um traust pegar öðrum breytum er haldið föstum. Niðurstaðan er sú að ímyndarpátturinn samfélagsleg ábyrgð hefur mest framlag með beta gildið 0,35. Par á eftir kemur persónuleg pjónusta (beta $=0,285$ ), í priðja sæti er leggur góðum málum lið (beta $=0,22$ ) og sá ímyndarpáttur sem hefur minnst framlag við að spá fyrir um breytileikann í trausti er spilling (beta $=0,15$ ). 


\section{Umræða}

Niðurstöður rannsóknarinnar styðja pað sjónarmið að pað getur tekið langan tíma að byggja upp traust en hægt er að glata pví á einni nóttu (sjá mynd 1). Pó svo að bönkunum hafi orðið nokkuð ágengt í pví að endurheimta fyrri stöðu sína virðist enn langt í land hvað ímynd varðar. Niðurstöður styðja einnig pað sjónarmið að ímynd sé byggð á mismunandi breytum (sjá t.d. Hsieh, Pan og Setiono, 2004) sem geta verið innbyrðis háðar. Pannig virðist traust, sem er í eðli sínu ímyndarpáttur, vera samsett úr nokkrum páttum svo sem ánægju viðskiptavina og samfélagslegri ábyrgð en rannsóknir sýna að samfélagsleg ábyrgð er mikilvæg fyrir banka (sjá Branco og Rodriques, 2006).

Svo svarað sé fyrri rannsóknarspurningunni, hvaða ímyndarpættir spá fyrir um traust til íslenskra banka, er niðurstaðan sú að fjórir ímyndarpættir, leggur góðum málum lið, persónuleg pjónusta, samfélagsleg ábyrgð og spilling skýra rúm $68 \%$ af breytileikanum í trausti. Allir pessir ímyndarpættir hafa jákvæða stuðla nema spilling, sem er rökrétt par sem traust og spilling eru andstæðir ímyndarpættir.

Sé litið til seinni rannsóknarspurningarinnar, hvaða ímyndarpættir hafa mest vægi pegar spáð er fyrir um traust til íslenskra banka, pá kemur í ljós að ímyndarpátturinn samfélagsleg ábyrgð hefur mest framlag, pá persónuleg pjónusta, í priðja sæti er ímyndarpátturinn leggur góðum málum lið og minnsta framlagið hefur spilling. Vert er að benda á að fylgnin á milli ímyndarpáttanna samfélagsleg ábyrgð annars vegar og leggur góðum málum lið hins vegar er nokkuð há $(\mathrm{r}=0,64)$ og kæmi pví til álita að sleppa annarri breytunni í spálíkanagerðinni. Sé pað gert (leggur góðum málum lið) kemur í ljós að útskýringarhlutfalli $\mathrm{R}^{2}$ lækkar aðeins og verður 0,64 (tilviljun að hér er sama gildi og fyrir fylgni). Рað áhugaverða sem gerist við petta er að ímyndarpátturinn samfélagsleg ábyrgð fær mun meira afgerandi vægi en áður og pví ættu stjórnendur að veita peim pætti sérstaka athygli.

Peir ímyndarpættir sem ekki höfðu marktæka stuðla í aðhvarfsjöfnunni voru framsækni, nútímalegur og gamaldags og hafa pví ekki framlag pegar kemur að pví að spá fyrir um breytileikann í trausti. Pessir pættir hafa pó mikið framlag pegar kemur að pví að meta ímynd en umræða um pað er fyrir utan viðfangsefni pessarar greinar.

Ímynd bankanna er óápreifanleg eign sem hjálpar peim við aðgreina sig frá öðrum og eykur líkur á markaðslegum árangri. Prátt fyrir pað hafa rannsóknir sýnt að fjármálastofnanir gera sér ekki alltaf grein fyrir pessu sem getur að hluta til verið vegna pess að aðaláhersla peirra er á efnahagslegar niðurstöður í stað pess að meta árangur byggðan á styrk vörumerkis eða ímyndar á markaðnum (Chernatony og Cottam, 2006). Í pessari rannsókn hefur ímynd fjármálstofnana verið rannsökuð. Rannsóknin leggur sitt af mörkum til fræðanna með pví að sýna hvaða pættir eða eiginleikar spá fyrir um traust og hverjir páttanna eru peir mikilvægustu. Ein aðalniðurstaða pessarar rannsóknar er sú að vænlegasta leiðin til að byggja upp traust er sú að styrkja ímyndarpáttinn samfélagslega ábyrgð og nýtist hún pannig stjórnendum. 


\section{Heimildir}

Ballantyne, D. og Aitken, R. (2007). Branding in B2B markets: Insights from the servicedominant logic of marketing. Journal of Business $\mathcal{E}$ Industrial Marketing, 22(6), 363-371.

Barney, J. og Hansen, M., (1994). Trustworthiness as a source of competitive advantage. Strategic Management Journal, 15(1), 175-190.

Blois, K. J. (1999). Trust in business to business relationships: An evaluation of its status. Journal of Management Studies, 36(2), 197-215.

Branco, M. C. og Rodrigues, L. L. (2006). Communication of corporate social responsibility by Portuguese banks: A legitimacy theory perspective. Corporate Communications: An International Journal, 11(3), 232-248.

Braun-LaTour, K. A., LaTour, M. S. og Zinkhan, G. M. (2007). Using childhood memories to gain insight into brand meaning. Journal of Marketing, 71(2), 45-60.

Bravo, R., Montaner, T., og Pina, J. M. (2009). The role of bank image for customers versus non-customers. International Journal of Bank Marketing, 27(4), 315-334.

Brown, T. J., Dacin, P. A., Pratt, M. G. og Whetten, D. A. (2006). Identity, intended image, construed image, and reputation: An interdisciplinary framework and suggested terminology. Academy of Marketing Science. Journal, 34(2), 99-106.

Bunger, A. C. (2013). Administrative coordination in nonprofit human service delivery networks: The role of competition and trust. Nonprofit and Voluntary Sector Quarterly, 42(6), 1155-1175.

Burns, A. C. og Bush, R. F. (2006). Marketing research (5th ed.). New Jersey: Pearson/Prentice Hall.

Chatura, R. og Prabhu, J. (2003). On the relative importance of customer satisfaction and trust as determinants of customer retention and positive word of mouth. Journal of Targeting, Measurement and Analysis for Marketing, 12(1), 82-90.

Chen, T., Chang, P.-L. og Chang, H.-S. (2005). Price, brand cues, and banking customer value. International Journal of Bank Marketing, 23(3), 273-291.

Chernatony, L. de og Cottam, S. (2006). Why are all financial services brands not great? Journal of Product and Brand Management, 15(2), 88-97.

Davis-Sramek, B., Droge, C., Mentzer, J. T. og Myers, M. B. (2009). Creating commitment and loyalty behavior among retailers: What are the roles of service quality and satisfaction? Journal of the Academy of Marketing Science, 37(4), 440-454.

De Bondt, W., (2010). The crisis of 2008 and financial reform. Qualitative Research in Financial Markets, 2(3), 137-156.

Doney, P. M., og Cannon, J. P. (1997). An examination of the nature of trust in buyer-seller relationships. Journal of Marketing, 61(2), 35.

Dutton, J. E. og Dukerich, J. M. (1991). Keeping an eye on the mirror: Image and identity in organizational adaptation. Academy of Management Journal, 34(3), 517-554.

Farquhar, J. D. og Panther, T. (2008). Acquiring and retaining customers in UK banks: An exploratory study. Journal of Retailing and Consumer Services, 15(1), 9-21.

Flint, D. J., Blocker, C. P. og Boutin Jr., P. J. (2011). Customer value anticipation, customer satisfaction and loyalty: An empirical examination. Industrial Marketing Management, 40(2), 219-230.

Fombrun, C. (1996). Reputation: Realizing value from the corporate image. Boston, MA: Harvard Business Press. 
Gardner, B. B. og Levy, S. J. (1955). The product and the brand. Harvard Business Review, 33(2), 33-39.

Gefen, D. (2000). E-commerce: The role of familiarity and trust. Omega, 28(6), 725-737.

Gilbert, D. U. og Behnam, M. (2013). Trust and the United Nations global compact: A network theory perspective. Business and Society, 52(1), 135-169.

Hess, J. og Story, J. (2005). Trust-based commitment: Multidimensional consumer-brand relationships. Journal of Consumer Marketing, 22(6), 313-322.

Holland, C. P. (1998). The importance of trust and business relationships in the formation of virtual organisations. Organizational Virtualness. Organizational Virtualness (workshop í Bern), 53-64.

Howcroft, J. B. (1991). Customer satisfaction in retail banking. The Service Industries Journal, 11(1), 11-17.

Hsieh, M. H., Pan, S.-L. og Setiono, R. (2004). Product-, corporate-, and country-image dimensions and purchase behavior: A multicountry analysis. Academy of Marketing Science Journal, 32(3), 251-270.

Jones, S., Wilkens, M., Morris, P. og Masera, M., (2000). Trust requirements in e-business. Communications of the ACM, 43(12), 80-87.

Kantsperger, R. og Kunz, W.E., (2010). Consumer trust in service companies: A multiple mediating analysis. Managing Service Quality, 20(1), 4-25.

Keller, K. L. (1993). Branding shortcuts. Marketing Management, 11(3), 120-164.

Keller, K. L. (2008). Strategic brand management, building, measuring, and managing brand equity. Upper Saddle River: Prentice-Hall.

Lewis, B. R. og Soureli, M. (2006). The antecedents of consumer loyalty in retail banking. Journal of Consumer Behaviour, 5(1), 15-31.

Lin, N. H. og Lin, B. S. (2007). The effect of brand image and product knowledge on purchase intention moderated by price discount. Journal of International Management Studies, (8), 121-132.

Lov, C. H. og Wirtz, J. (2011). Service marketing: People, technology, strategy (7th útg.). New Jersey: Prentice Hall.

Merz, M. A., He, Y. og Vargo, S. L. (2009). The evolving brand logic: a service-dominant logic perspective. Journal of the Academy of Marketing Science, 37(3), 328-344.

Moorman, C., Zaltman, G., og Deshpande, R. (1992). Relationships between providers and users of market research: The dynamics of trust within and between organizations. Journal of Marketing Research (JMR), 29(3), 314-328.

O'Loughlin, D. og Szmigin, I. (2005). Customer perspectives on the role and importance of branding in Irish retail financial services. International Journal of Bank Marketing, 23(1), 827.

Oliver, R. L. (1997). Satisfaction: A behavioral perspective on the consumer. New York: McGrawHill.

Pennington, R. Wilcox, D. og Grover, V. (2004). The role of system trust in business-toconsumer transactions. Journal of Management Information Systems, 20(3), 197-226.

Rambocas, M., Kirpalani, V. M og Simms, E. (2014). Building brand equity in retail banks: The case of Trinidad and Tobago. International Journal of Bank Marketing, 32(4), 300-320.

Ratnasingham, P. (1998). The importance of trust in electronic commerce. Internet Research, $8(4), 313-321$.

Reichheld, F. F. og Sasser Jr., W. E. (1990). Zero defections: Quality comes to services. Harvard Business Review, 68(5), 105-111. 
Rindell, A. (2007). Image heritage. The temporal dimension in consumers' corporate image constructions. Helsinki: Hanken School of Economics.

Rindell, A. (2013). Time in corporate images: Introducing image heritage and image-in-use. Qualitative Market Research: An International Journal, 16(2), 197-213.

Ríkisendurskoðun (2009). Endurskoðun ríkisreiknings 2008. Reykjavík: Ríkisendurskoðun.

Samkeppniseftirlitið (2011). Samkeppni á bankamarkaði. Reykjavík: Samkeppniseftirlitið.

Schurr, P. H., og Ozanne, J. L. (1985). Influences on exchange processes: Buyers' preconceptions of a seller's trustworthiness and bargaining toughness. Journal of Consumer Research, 11(4), 939-953.

Shugan, S. M. (2005). Brand loyalty programs: Are they shams? Marketing Science, 24(2), 185193.

Sirdeshmukh, D., Singh, J. og Sabol, B., (2002). Consumer trust, value, and loyalty in relational exchanges. Journal of Marketing, 66(1), 15-37.

Smit, E., Bronner, F. og Tolboom, M. (2007). Brand relationship quality and its value for personal contact. Journal of Business Research, 60(6), 627-633.

Solms, M. og Turnbull, O. (2002). Brain and the inner world: An introduction to the neuroscience of the subjective experience. Other Press, LLC.

Souiden, N., Kassim, N. M. og Hong, H.-J. (2006). The effect of corporate branding dimensions on consumers' product evaluation: A cross-cultural analysis. European Journal of Marketing, 40(7/8), 825-845.

Tsai, S. (2011). Fostering international brand loyalty through committed and attached relationships. International Business Review, 20(5), 521-534.

Wirtz, J. (2003). Halo in customer satisfaction measures: The role of purpose of rating, number of attributes and customer involvement. International Journal of Service Industry Management, 14(1), 96-119.

Xie, Y. og Peng, S. (2009). How to repair trust after negative publicity: The roles of competence, integrity, benevolence, and forgiveness. Psychology and Marketing, 26(7), 572-589.

Yoo, B., Donthu, N. og Lee, S. (2000). An examination of selected marketing mix elements and brand equity. Academy of Marketing Science.Journal, 28(2), 195.

Zahir, O. (2014). Conceptual framework development for customer loyalty in Malaysian commercial banking industry. International Journal of Managment, IT and Engineering, 4(2), 197-214.

Pórhallur Guðlaugsson (2008). Ímynd banka og sparisjóða. Í Ingjaldur Hannibalsson, (ritstjóri), Rannsóknir í félagsvísindum IX (bls. 601-613). Reykjavík: Félagsvísindastofnun Háskóla Íslands.

Pórhallur Guðlaugsson og Friðrik Eysteinsson (2010). Áhrif bankahrunsins á tryggð viðskiptavina. Í Vorráðstefna Viðskiptafræðistofnunar (bls. 148-158). Reykjavík: Háskóli Íslands. 